ET

63,9

\section{6}

Received 29 July 2020

Revised 13 January 2021 28 March 2021

12 June 2021

Accepted 11 September 2021

\title{
Towards competence-oriented higher education: a systematic literature review of the different perspectives on successful exit profiles
}

\author{
Sanna Brauer \\ School of Professional Teacher Education, Oulu University of Applied Sciences, \\ Oulu, Finland and \\ Learning and Educational Technology Research Unit, University of Oulu, \\ Oulu, Finland
}

\begin{abstract}
Purpose - The twenty-first century education system seeks to meet the societal demands of economic effectiveness and the unique professional development needs of individuals. This paper aims to discuss the qualities of competence-oriented educational processes and the recent movement towards competence-based curricula in higher education.

Design/methodology/approach - This study follows a systematic literature review (SLR) methodology to explore the concept of competence within the context of educational science. The subsequent thematic synthesis analyses the findings of reviewed publications regarding graduate attributes in competence-oriented higher education and their perspectives and working-life expectations on exit profiles.

Findings - Interest in competence-oriented education, training and learning has grown in recent years, resulting in numerous theoretical and technical pedagogical applications in higher education. Nonetheless, ambiguous terminology presents a significant challenge, which is demonstrated by the inconsistent language of the study's results. Moreover, there is an obvious need for teachers' in-service training. The qualitative synthesis of this article will be useful for both educational and working life sectors to inform and promote different perspectives on competence-oriented educational processes. A clear articulation of competences is crucial for reforming higher education to meet students' interests and recognise their work-life needs.

Originality/value - The concept of competence has been under-investigated in higher education research and practices. This study offers novel insights and practical implications for competence-oriented learning concerning the paradigmatic change across higher education.
\end{abstract}

Keywords Competence-oriented education, Curricular development, Exit profile, Higher education,

Working life

Paper type Research paper

\section{Introduction}

The latest industrial revolution, Industry 4.0, and the related drive for global economic growth have challenged curriculum planning. Higher education (HE) is expected to

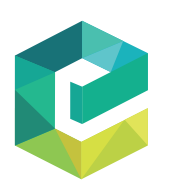

Education + Training Vol. 63 No. 9, 2021 pp. $1376-1390$ Emerald Publishing Limited 0040-0912

DOI 10.1108/ET-07-2020-0216
(C) Sanna Brauer. Published by Emerald Publishing Limited. This article is published under the Creative Commons Attribution (CC BY 4.0) licence. Anyone may reproduce, distribute, translate and create derivative works of this article (for both commercial and non-commercial purposes), subject to full attribution to the original publication and authors. The full terms of this licence may be seen at http:// creativecommons.org/licences/by/4.0/legalcode

Many thanks to Dr. Maarit Virolainen (University of Jyväskylä) for her insightful comments on this article and her encouraging support. This work was supported by the Work-Integrated Pedagogy in Higher Education project (WORKPEDA), funded by the Finnish Ministry of Education and Culture. No potential conflict of interest is reported by the author. 
provide more accurate evidence of qualitative learning outcomes, particularly because institutional funding has been linked to student achievement, graduation rates and rapid employment (Rhodes, 2012). To meet societal demands, educational institutions have had to reconsider, which attributes are most important to graduates, and the extent to which various programmes develop these desired qualities (Little and McMillan, 2014). These exemplar statements of graduate attributes and preferred exit profiles support a common understanding of recognised professional competences expected by graduates (International Engineering Alliance, 2013). These attributes should reflect graduates' individual potential to acquire competences to practise at the relevant professional level and should assist students' overall societal integration upon graduating.

Educational institutions are encouraged to modernise approaches to learning and teaching in HE (European Union, EU, 2017). The European Union promotes the provision of competence-oriented education, training and learning, establishing related good practices and better support of educational staff (EU, 2018). The concept of "competence" is connected to different standards and frameworks that enhance the assessment of learning outcomes (Mäkinen and Annala, 2010). According to the European Qualifications Framework $(\mathrm{EQF})$, competence is described as the "proven ability to use knowledge, skills and personal, social and/or methodological abilities in work or study situations and professional and personal development" (EU, 2008, p. 4) and emphasises personal responsibility and autonomy.

There are several ways of conceptualising "competence" and various implementations of "competence-based" education and training. Institutional policies for official examination and assessment of competences differ in theory and practice (Sadler, 2005). A variety of supporting constructions, such as the EQF, the ECVET (European Credit System for Vocational Education and Training) and the ECTS (European Credit Transfer System in Higher Education) have been introduced to facilitate evaluation processes (Karseth, 2006; Lee et al., 2017). This article focuses on "competences" as outlined in The European Reference Framework of Key Competences for Lifelong Learning (EU, 2018) and on the competencebased approach, a recent movement in $\mathrm{HE}$ from knowledge-based towards competence-based curricula (UNESCO, 2019).

The concept of competence can also be considered an "organising principle of curriculum" (UNESCO, 2019) that connects authentic work-life experiences with educational institutional learning (Jonnaert et al., 2007). A standardised curriculum is a set curricular ideal with specific content and skills (Karseth, 2006) created to enhance learning outcomes and to provide equal and egalitarian opportunities for personal development. Curricular discourses are sectoral and vocational in nature (Karseth, 2006; Mäkinen and Annala, 2012) and require disciplinary efforts to determine achievement levels and update assessments (Barman and Konwar, 2011).

Moreover, efficient and systematic competence development requires a consensus regarding assessment criteria to create policies that can be appropriately applied (Sadler, 2005). Schneckenberg et al. (2011) argue that "despite the demand of firms for versatile graduates and the obvious potential of learning technologies to foster competence development of students, universities need to establish institutional strategies to make this pedagogical change happen” (p. 747). The recent shifts toward competence-based curricula, degree and higher level apprenticeships (Mulkeen et al., 2019) and novel practices like micro-credentialing $(\mathrm{OECD}, 2020)$ reflect this desire for pedagogical changes to integrate professional competences across HE. Although new curricula appear frequently, the processes of updating required competences must be flexible enough to respond to changes in society and to meet new job opportunities in exceptional situations like COVID-19. 
ET

63,9

1378

\section{Theoretical framework}

This discussion introduces and describes key competence-oriented educational concepts from the last decades. Practices are discipline-specific and vary significantly between countries. There are also differences between academic research universities and universities of applied sciences (UAS). For example, in Finland UAS degree programmes are based on the competence-based curricula and engage so-called "work and study" models created for workintegrated learning (Mäkelä and Moiso, 2017), whereas the shift towards competence-based approaches within universities has just begun (Lavonen, 2020; Levy et al., 2019). Studies of these models offer encouraging views on competence-oriented education, training and learning as a sustainable way to increase students' capabilities in HE (e.g. Brauer, 2019; Mäkelä and Moiso, 2017). This study draws attention to the potential of the competencebased approach to define the required competences and visualise the gap between existing and desired competences (Brauer, 2019; Hodge and Lear, 2011).

\section{The concept of competence}

The debate about the concept of competence has been ongoing within the educational sector for decades, varying by extent and focus (Mulder and Winterton, 2017). The concept also holds different meanings in science and practise (Costley, 2001; Schaffar, 2019). There is a paradigmatic difference between the concepts of "competency" and "competence" that have been provided with a variety of explanations. For example, Mäkinen and Annala (2010) define competency as a concept that refers to an individual's potential as a whole. They call attention to the potential of an individual's human capital to implement and demonstrate a particular competence. Schaffar (2019) recently discussed this ambiguous notion of competence as "a key concept in today's educational discussion, where it combines both a psychological meaning of an inner disposition and a sociological meaning as a category that organizes tasks and power-relations in public and private institutions" (p. 111). By this regard, a clear definition depends on a concrete context and can be interpreted in different ways (Hodge and Lear, 2011).

Generally, competence-based approaches aim to enhance the work-life relevance of education to the meet needs of the labour market and societal development. Moreover, the concept of Degree and Higher Level Apprenticeships (D\&HLAs) "offers employers the opportunity to develop their business through filling higher level skills and knowledge gaps and improving employee motivation" (Mulkeen et al., 2019, p. 234). Hence, the transfer of knowledge from educational to workplace settings is complex by nature (Eraut, 2004; Billett, 2001; Mulkeen et al., 2019), and the employability of a student is always context-dependent and situation-specific (Yorke, 2006). Connections to competence development, to performance motivation theories and to entrepreneurship form a multifaceted theoretical construction that allows for a variety of interpretations (Mulder and Winterton, 2017). Mulder and Winterton (2017) also point out both the unifying efforts and competing definitions of competence, as applied in international educational policy-making and international or national qualification, certification or credit frameworks.

However, the concept also relates to the actual implementation of competence-based curricula, instruction and assessment in practice, a combination of attributes describing the correspondence between learning outcomes and competences but also the relationship between learning outcomes and generic descriptions (Kennedy and McCarthy, 2016). According to Malone and Supri (2012), the movement towards competence-based curricula aims to "increase the rigour and relevance of the curriculum, move students beyond a focus on the memorisation and regurgitation of scientific facts, and better enable them to understand scientific principles and apply them to the practice” (p. 241). Particularly, workbased programmes challenge higher education institutions (HEIs) and partnering 
organisations to plan and implement quality training to meet the unique needs of working life (Costley, 2001). Competence-based education is also an effective way to train students to achieve superior performance levels (Mulder and Winterton, 2017).

The etymological foundation for assessing competences shares its roots with the concept of competition (Schaffar, 2019). Competence-based assessment is important for making educational goals explicitly known through criteria-based discourses. The approach is considered an effective way to form educational grading policies (Sadler, 2005); but despite years of shifting towards competence-based curricula, few researchers or practitioners have designed assessment systems in $\mathrm{HE}$ that specifically evaluate competence-based approaches (Dannefer and Henson, 2007). For example, Klein-Collins (2013) characterises the competence-based approach as a student-centred way of learning the "doing" that ensures quality graduates, with assessments that validate learning. Klein-Collins' findings align with recent research (e.g. Brauer, 2019) emphasising the motivational factors of this pragmatic approach and providing suggestions to better demonstrate the required competences in working life. While the concepts of competence-oriented education, training and learning have been the subjects of ongoing debate among various disciplines, critical analysis of practical applications remains vague and inconclusive (Lans et al., 2008; Malone and Supri, 2012).

\section{Aim and research questions}

The overall research problem of this study stems from the discrepancy between increased interest in competence-oriented educational practises in $\mathrm{HE}$ and the quality of research that must inform and promote the competence-based approach in the curricular development of HEIs. The current recommendations and policies (EU, 2018; UNESCO, 2019) were emphasised outlining the research questions. The competence-based curricula and course descriptions offer the opportunity to illuminate the gap between existing and desired competences. The objective of this study is to review existing literature in the field of educational science and to clarify the different perspectives on the concept of competence concerning successful exit profiles in HE.

The following research questions guide this study:

$R Q 1$. What kinds of competences do HE graduates desire to achieve during their studies?

$R Q 2$. What kinds of expectations does working life have for students' competences?

Based on HE research from the last decade, this article addresses the recent challenges and opportunities arising from the shift towards competence-oriented education, training and learning (EU, 2017; EU, 2018) and competence-based curricula (UNESCO, 2019).

\footnotetext{
Methodology

The research in this study relies on a systematic literature review (SLR) methodology to collate and extensively analyse relevant sources (Boelens et al., 2017; Borrego et al., 2014; Sun et al., 2018), to provide evidence on developing assessment practices and to address the tensions among the perspectives of various actors. This methodology allows for systematic knowledge aggregation, clarification and the interpretation (Gessler and Siemer, 2020) of varying notions on the concept of competence. A comprehensive search was conducted over multiple databases excluding grey literature. Because a documented and structured process enhances the reliability and validity of the literature review (Sawyer, 2017), the following results are presented in the form of a qualitative synthesis based on two research questions, to enable the critical "evaluation of those concepts, arguments and different interpretations" (Hart, 2018, pp. 3-4).
} 
ET

63,9

\section{0}

Table 1.

Five most relevant categories
Search stages

Two search stages were used to collate research relevant to this study. In both searches, articles were selected according to their titles, abstracts and keywords. The search began by reviewing exploratory and empirical research that examined graduate and exit profiles involving competences and $\mathrm{HE}$ and resulted in 75 articles. The search terms included "competence" and "higher education" and "exit profile" and/or "graduate attribute". According to selected criteria, articles had to include "higher education" as a keyword.

The second search focused on competence and $\mathrm{HE}$ (these had to be included as keywords) using the following search terms: competence and higher education and criteria-based assessment and/or competence-based criterion and/or competence-based assessment. This search resulted in 114 articles (79 full articles available online).

The FINNA search service was employed to retrieve information from scientific databases including Eric (ProQuest), Scopus (Elsevier), Social Sciences Citation Index (Web Of Science), Taylor \& Francis Online- Journals, OneFile (GALE) and Informa- Taylor \& Francis (CrossRef). These databases were selected because of the accessible multidisciplinary collections and their relevance to the topic.

This study focuses on recent research, including peer-reviewed journal articles published between 2009 and 2019. These include international studies, but omit articles not published in English. Short conference articles without clear descriptions, books and book chapters and scholarly reviews were also excluded. These exclusion criteria assisted in focussing the research and selecting appropriate references (Boelens et al., 2017).

\section{Analysis}

The data-driven content analysis was conducted because of its suitability for both qualitative and quantitative research (Borrego et al., 2014; Seuring and Gold, 2012). Two levels of content analysis (Seuring and Gold, 2012) were applied by first statistically analysing the content of articles based on their titles, abstracts and keywords. During this first stage, FINNA search service tools were employed to categorise and quantify the information. This approach allowed the researchers to focus on the selected aspects of the material, to "translate" the documents into preliminary coding categories and to classify the materials therein (Schreier, 2012).

The first five categories included $61 \%$ (115) of the 189 total articles (Table 1). Other categories that emerged included competence-building technologies and student selection (sorting) into education. Each of these categories consisted of one to four articles, with eight articles classified under "generic skills related to work-life competences". This category was excluded from the body of pooled research because it does not respond to the research questions.

It is also notable that one search (All fields: competence and higher education and exit profile and/or graduate attribute must include keyword higher education) provided significantly fewer relevant results $(n=28)$ than using the following search terms:

\section{Category}

Result

Competence-based assessment

Development of competence-based assessment practices and curricula

Exit profile/Graduate attributes

Professional competences

Total articles 
competence and higher education and criteria-based assessment and/or competence-based criterion and/or competence-based assessment $(n=94)$.

In a systematic literature review, the researcher should establish clear principles to steer content analysis and inform methodological decisions (Borrego et al., 2014; Mayring, 2000; Seuring and Gold, 2012). The second stage of analysis focused on the five most relevant categories. After becoming familiar with the selected sources available online $(n=76)$, a total of 20 articles were retrieved (three to five for each category) for content analysis based on the research questions, keywords and preliminary categorisation (Table 1).

A separate document was established based on these preconditions. The information extracted was then organised based on the deductive categorisation originally structured in the FINNA service involving the articles' details (authors, year published ans title). The subsequent stage of analysis ascertained the actual content of the research based on the parameters, with regard to the categories from the first stage of analysis. The content was analysed from a semantic perspective, and recurrent themes were identified concerning both research questions.

\section{Results}

This section provides a qualitative analysis of previous work and summarises the content of the selected sources as they relate to both of this study's research questions. The authors provide detailed information about the reviewed articles' focus, context, data, methods and conceptual approaches (Table 2). The subsequent thematic synthesis involved the analysis of the reviewed publications regarding their content.

All resulting articles were published in different journals and represent a variety of sectoral publications. The qualitative synthesis draws upon examples of different cases within the surveyed research to address the tensions embedded in the different perspectives on competence-based HE. Results do not list individual competences based on educational structures with an emphasis on the subject area level. That is the content of studies like the Tuning Project, where the data are collected from both HE graduates and employees (Beneitone and Bartolomé, 2014). As Hart (2018) puts it, "synthesis is not simply a matter of reassembling the parts back into the original order, but looking for a new order" (p. 197). In the following subsections, the articles are presented and analysed to answer both research questions.

\section{HE graduates' perspectives on competence-based higher education}

The articles pertaining to research question one (RQ1) brought up different perspectives. First, it was found that students emphasise the importance of general studies. Second, they stress the importance of receiving feedback for building professional identities that pertain to their own professional competence levels. Third, the students consider assessments necessary for building their professional identities. Fourth, students need ways to assess and communicate their individual professional competences. HE graduates expect to have a certain discipline-focused, general perspective to understand dependencies among different phenomena; they seek to achieve a sound knowledge of the content in their areas of specialisation (Isopahkala-Bouret et al., 2011). For example, Isopahkala-Bouret et al. (2011) emphasise the fact that university graduates appreciate learning traditional academic skills. They also consider the ability to use scientific terms, expert vocabulary and theoretical concepts as an asset and consider academic skills more important for their future careers than practical know-how on work-related issues. As Isopahkala-Bouret et al. (2011) note, "One can learn such knowledge on the job, and it is not necessary to integrate it into academic studies" (p. 31). These sentiments beg the question, does a competence-based approach benefit HE students at all? 
ET
63,9

\section{2}

Table 2.

Results of the coding of the twenty selected articles

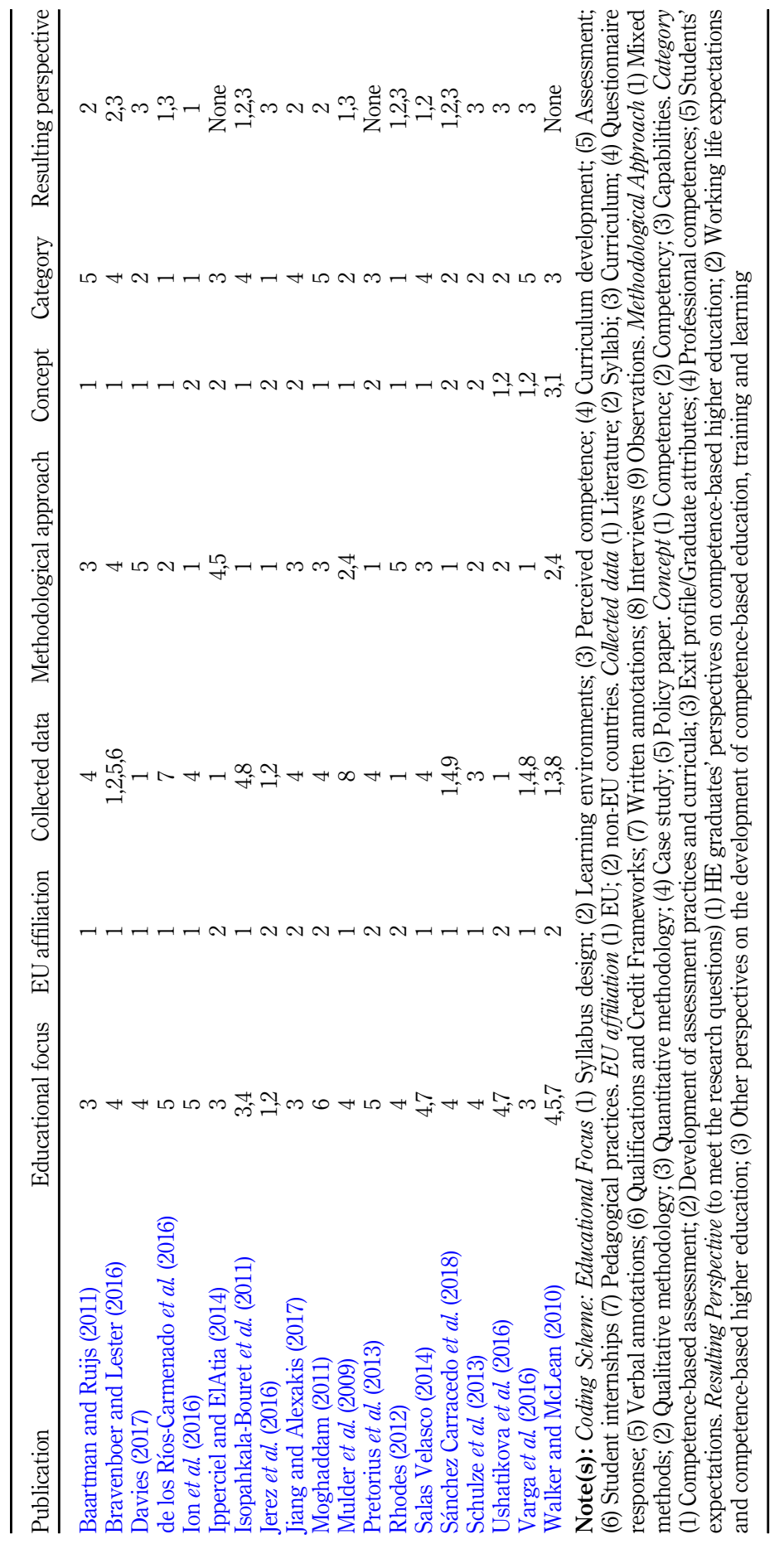


From the perspective of building professional identity, students form several expectations of and about themselves during their studies. They tend to overestimate their skills and knowledge at the beginning of their studies while underestimating their competences upon graduating (Baartman and Ruijs, 2011; Moghaddam, 2011). Student organisations stress the importance of giving and receiving professional feedback in mastering certain competences (Mulder et al., 2009). The issues regarding assessment are prevalent in the findings of de los Ríos-Carmenado et al. (2016), which indicate that $25 \%$ of students believe assessment systems help them to develop competences like organisation and planning. Students' points of view must be considered when developing assessments and teaching practices (de los RíosCarmenado et al., 2016). Furthermore, optimal feedback must cover one or more aspects of the learning exercise, focussing on a product, the process or the progress recorded in the student's learning (Ion et al., 2016). Ordonez (2014) argues that students should be assessed on what they know rather than the amount of time they spend in a classroom. In this way, working life appears to be a suitable learning environment for competence development as well (Salas Velasco, 2014).

New digital tools offer the ability to capture students' learning and learning experiences throughout their educational careers. Mulder et al. (2009) indicate that "representatives of student organisations value the notion of competence development and preparation for the labour market" (p. 767). In practice, this observation means that students seek to connect goals of academic proficiency with actual competence development. The preferred tool could be personal portfolios or development plans that integrate competences (and ensuring competence) into academic programmes; these skills include communication, critical reflection, information literacy, teamwork and project management (Mulder et al., 2009). Moreover, Rhodes (2012) argues that rich and robust e-portfolios or other forms of professional media can deepen students' learning and their understandings of their strengths and weaknesses. Technology should be embraced when it allows for efficient and costeffective identification and recognition of competences by external entities as evidence of student learning at the levels associated with quality performance. Indeed, technological integration is crucial for graduates and employers, as well as educational institutions, when it comes to pedagogical improvement (Rhodes, 2012).

In many cases, learning objectives for students are implicit, not explicit (Rhodes, 2012). However, assuming that students will comprehend these objectives on their own diminishes the efficiency of HE (Rhodes, 2012, p. 40). Several studies (e.g. de los Ríos-Carmenado et al., 2016; Ordonez, 2014) note that students who follow competence-based education manage their learning better than other students. Because progress is not predetermined by course offerings and academic calendars, these students are given more autonomy to further their studies. In this context, de los Ríos-Carmenado et al. (2016) suggest that students should embrace taking an active role in their education instead of focussing on the given content. Their research confirms improvement among both students' grades and appreciation levels for professional competences based on the competence-based approach in HE (de los RíosCarmenado et al., 2016). Ultimately, competence-based education intends to enhance the motivation of students, along with their engagement in the learning process.

\section{Working life expectations and competence-based higher education}

The second research question (RQ2) concerns what kinds of expectations working life has for students' competences based on the reviewed research. According to the thematic synthesis, although HE places the most emphasis on technical knowledge, this trait appears to be the least valued by employers (Sánchez Carracedo et al., 2018). Various industries prioritise transversal, generic competences like teamwork skills and a willingness to learn (Jiang and Alexis, 2017; Salas Velasco, 2014), while HE continues to emphasise technical competences 
ET

63,9

\section{4}

and a results-orientated approach, along with the ability to work in multicultural and multidisciplinary environments (Sánchez Carracedo et al., 2018). Based on their findings concerning employers' views on mapped competence, Sánchez Carracedo et al. (2018) call for procedures that systematically assign the required professional expertise across the curriculum subjects to assure achievement of the competences. The relationship between desired competences and graduates' professional activities should be clear. Sánchez Carracedo et al. (2018) highlight social skills as especially desired competences in working life. Contrastingly, Isopahkala-Bouret et al. (2011) study how employers see the needs of working life based on EQF. Their results illustrate how employers emphasise the need for critical and independent thinking skills along with graduates' cognitive competence. Employers expect academic graduates to have profound specialised knowledge in their field and to possess the ability to integrate knowledge from different fields. Still, they do not necessarily consider this knowledge to be a very high-level competence (Isopahkala-Bouret et al., 2011, p. 35). These studies present two very different approaches. Furthermore, Ipperciel and ElAtia (2014) note that these graduate attributes are not homogeneous. Rather, attributes always relate to the context and the philosophy and values of the particular organisation.

Proficiency in key competences forms an integral part of the professional expertise required in the world of work. Sánchez Carracedo et al. (2018) note several studies that "emphasise the need to include professional competences in curricula, but much fewer studies on how to integrate them in a systematic way" (p. 450). Moreover, they point out that the competence-based approach requires the integration of professional competences into different courses, necessitating deliberate stages of planning and experience. Ushatikova et al. (2016) describe the purpose of introducing the competence-based approach in $\mathrm{HE}$ as one that "shall comply with the interests of students, teachers, employers and society as a whole, to give clear guidance to teachers and students" (p. 284). Nevertheless, Jerez et al. (2016) point out a significant tendency to develop learning processes in terms of quality and relevance. Ushatikova et al. (2016) conclude that HE should be based on carefully planned pedagogical processes that focus on the development of future professional expertise such as competence, responsibility, mobility, flexibility, adaptability and competitiveness.

\section{Conclusions and practical implications}

The purpose of this study was to discuss the qualities of competence-oriented education, training and learning to explore different views towards successful exit profiles in HE. Several studies included in the qualitative synthesis argue that the competence-based approach could be suitable for HE (e.g. de los Ríos-Carmenado et al., 2016; Mulder et al., 2009). References to the Bologna Process should be noted as well, including citizenship, lifelong employability, international mobility (Davies, 2017) and harmonisation of key competences on an international scale (Schulze et al., 2013). Economical education alternatives are in demand (Bravenboer and Lester, 2016; Ordonez, 2014), particularly given the fact that the number of jobs that require prerequisite HE remains stable. It should be also noted that high level competence development offers employers the opportunity to develop their business (Mulkeen et al., 2019). Both students and HE professionals prioritise the value of students to learn a wide range of skills and knowledge during their studies to adequately meet the challenges of contemporary global society (Sánchez Carracedo et al., 2018; Rhodes, 2012). Future employees should be trained to become responsible, resilient and competent professionals (Ushatikova et al., 2016) to overcome challenging situations of change, such as the COVID-19 global emergency. Achieving these goals requires carefully planned pedagogical processes. Based on relevant $\mathrm{HE}$ research from the last decade, this article sought to address the recent challenges and opportunities resulting from the shift towards competence-based curricula 
(UNESCO, 2019). As a result, the study uncovered differing views on exit profiles and graduate attributes in competence-oriented $\mathrm{HE}$.

The concept of desired competences remains indeterminable based on the accessible exploratory and empirical studies, but the results yielded from this study's investigation have provided various perspectives for exploring the gap between existing and desired competences. The challenges of competence-oriented education, training and learning reflect a fragmented approach to academic qualification and professional recognition systems. Still, interest in the competence-based approach has grown in recent years (Davies, 2017), even in terms of theoretical and technical pedagogical application development. Calls for clearly-articulated learning outcomes (Costley 2001; Rhodes, 2012) have already begun to reform HE. The actual practices, use of learning outcomes and competences in learning models do not always align with the original ideas of the syllabus design or criteria established in the curricula (Jerez et al., 2016; Struyven and De Meyst, 2010). Notably, there is no single competence-based model that suits every educational organisation (Davies, 2017; Ipperciel and ElAtia, 2014; Ushatikova et al., 2016). Indeed, Jerez et al. (2016) point out that standardisation is not appropriate for every student, and that there are significant differences between disciplines. The concerns of teaching staff regarding their own pedagogical competence must also be noted (de los Ríos-Carmenado et al., 2016; Jerez et al., 2016), which requires the provision of various pedagogical in-service training sessions.

Mulder and Winterton (2017) describe developmental efforts in terms of "continued confusion and diversity in approaches to competence" (p. 7) that complicate efforts to design and implement coordinated policies. The Bologna Process and EU legislation are neither fully integrated into educational planning nor are they geo-politically congruent (Davies, 2017). For instance, D\&HLAs offering a substantial view regarding working life expectations, were not included on the results as the studies related to higher education apprenticeships (e.g. Mulkeen et al., 2019) do not reference the concept of competence. However, this indicates only the quality of language not an actual research gap. Further frameworks must be developed to monitor, organise and assess the broad range of models for competence-oriented education, training and learning. The discourse surrounding EU legislation has recently adopted terminology that recognises professional qualifications (Davies, 2017). The results of this study confirm Davies' (2017) description of competences as value judgements which refer to sectoral professions and can vary widely (see also Billett, 2001).

The notion of competence features a variety of attributes that can be gathered under one umbrella, such as the key competences $(\mathrm{EU}, 2018)$ or the overarching framework of the EQF (EU, 2008). The EU's strong focus on the labour market requires a standard format to accurately express a learning outcome that covers all qualifications. Davies (2017) further emphasises the action taken to enhance the clarity of terminology. For example, "responsibility and autonomy" in the EQF's tabulation of levels, has been interpreted in many cases simply as "competence". A competence-based orientation could resolve the often unclear differentiation between "theory" and "practice", and between "knowledge" and "competence" (Bravenboer and Lester, 2016, p. 409) in HE. This indicates that the approach provides the economy and efficiency required to develop education that meets the needs of working life. Moreover, graduates and employers should have a mutual understanding of desired competences based on public evidence (Rhodes, 2012).

There is a clear need for competence-based pedagogical alternatives in research-based $\mathrm{HE}$, and new tools are required to develop coherent curricula (Sánchez Carracedo et al., 2018). The insights gained through this study expanded researchers' capacity to understand how different perspectives on the concept of competence could promote the shift towards competence-based curricula and support novel practical implications like micro-credentialing (OECD, 2020). 
ET

63,9

\section{Limitations}

This study faced three primary limitations. First, the exclusion of articles written in languages other than English limited the study's potential scope. Second, the study excluded contextual background information, and the review was not specifically focused on European competence-based education. Third, because the study was a systematic review of articles that focused on effective elements of graduate attributes and exit profiles, it was limited to a narrow focus on competence-oriented education, training and learning. The existing review corpus is resultantly small. Two articles, Pretorius et al. (2013) and Walker and McLean (2010), were initially included based on the search results but were eventually excluded from the qualitative synthesis because they failed to directly answer either research question. This limitation reflects the argument that language referring to the competence-based approach is inconsistent, which hinders precise results. Originally, these articles were included in the "Exit Profiles/Graduate Attributes" category, which consisted of only three studies. None of these articles sufficiently addressed the research questions. These limitations must be noted before commencing future research on the impact of competence-based $\mathrm{HE}$.

\section{References}

Baartman, L. and Ruijs, L. (2011), "Comparing students' perceived and actual competence in higher vocational education", Assessment and Evaluation in Higher Education, Vol. 36 No. 4, pp. 385-398.

Barman, A. and Konwar, J. (2011), "Competency-based curriculum in higher education: a necessity grounded by globalization”, Revista Romaneasca Pentru Educatie Multidimensionala, Vol. 3 No. 6, pp. 7-15.

Beneitone, P. and Bartolomé, E. (2014), "Global generic competences with local ownership: a comparative study from the perspective of graduates in four world regions", Tuning Journal For Higher Education, Vol. 1 No. 2, pp. 303-334, doi: 10.18543/tjhe-1(2)-2014pp303-334.

Billett, S. (2001), "Knowing in practice: re-conceptualising vocational expertise", Learning and Instruction, Vol. 11, pp. 431-452, doi: 10.1016/S0959-4752(00)00040-2.

Boelens, R., De Wever, B. and Voet, M. (2017), "Four key challenges to the design of blended learning: a systematic literature review", Educational Research Review, Vol. 22, pp. 1-18, doi: 10.1016/j. edurev.2017.06.001.

Borrego, M., Foster, M.J. and Froyd, J. (2014), "Systematic literature review in engineering education and other developing interdisciplinary fields", Journal of Engineering Education, Vol. 103 No. 1, pp. $45-76$.

Brauer, S. (2019), Digital Open Badge-Driven Learning: Competence-Based Professional Development for Vocational Teachers, (Doctoral dissertation), Acta Universitatis Lapponiensis 380, Lapland University Press, Rovaniemi.

Bravenboer, D. and Lester, S. (2016), "Towards an integrated approach to the recognition of professional competence and academic learning”, Education and Training, Vol. 58 No. 4, pp. 409-421, doi: 10.1108/ET-10-2015-0091.

Costley, C. (2001), "Organizational and employee interests in programs of work based learning", The Learning Organization, Vol. 8 No. 2, pp. 58-63, doi: 10.1108/09696470110387991.

Dannefer, E. and Henson, L. (2007), "The portfolio approach to competency-based assessment at the cleveland clinic lerner college of medicine", Academic Medicine, Vol. 82 No. 5, pp. 493-502, doi: 10.1097/ACM.0b013e31803ead30.

Davies, H. (2017), "Competence-based curricula in the context of Bologna and EU higher education policy", Pharmacy: Journal of Pharmacy, Education and Practice, Vol. 5 No. 2, doi: 10.3390/ pharmacy5020017.

de los Ríos-Carmenado, I., Sastre-Merino, S., Fernández Jiménez, C., Núñez del Río, M., Reyes Pozo, E. and García Arjona, N. (2016), "Proposals for improving assessment systems in higher 
education: an approach from the model working with people", Journal of Technology and Science Education, Vol. 6 No. 2, pp. 104-120, doi: 10.3926/jotse.192.

Eraut, M. (2004), "Informal learning in the workplace", Studies in Continuing Education, Vol. 26 No. 2, pp. 247-273, doi: 10.1080/158037042000225245.

European Union (2008), "Recommendation on the establishment of the European Qualifications Framework for lifelong learning”, Official Journal of the European Union, C 111, Vol. 51, pp. 1-7.

European Union (2017), "Council conclusions on a renewed EU agenda for higher education", Official Journal of the European Union, C 429, Vol. 60, pp. 3-7.

European Union (2018), "Recommendation on key competences for lifelong learning", Official Journal of the European Union, C 189, Vol. 61, pp. 1-6.

Gessler, M. and Siemer, C. (2020), "Umbrella review: methodological review of reviews published in peer-reviewed journals with a substantial focus on vocational education and training research", International Journal for Research in Vocational Education and Training, Vol. 7 No. 1, pp. 91-125, doi: 10.13152/IJRVET.7.1.5.

Hart, C. (2018), Doing a Literature Review: Release the Research Imagination, 2nd ed., Sage Publications, London.

Hodge, K. and Lear, J.L. (2011), "Employment skills for 21st-century workplace: the gap between faculty and student perceptions", Journal of Career and Technical Education, Vol. 26 No. 2, pp. 28-41.

International Engineering Alliance (2013), "Graduate attributes and professional competencies", version 3:21, available at: http://www.ieagreements.org/assets/Uploads/Documents/Policy/ Graduate-Attributes-and-Professional-Competencies.pdf (accessed 28 July 2020).

Ion, G., Cano, E. and Cabrera, N. (2016), "Competency Assessment Tool (CAT). The evaluation of an innovative competency-based assessment experience in higher education", Technology, Pedagogy and Education, Vol. 25 No. 5, pp. 631-648, doi: 10.1080/1475939X.2015.1134635.

Ipperciel, D. and ElAtia, S. (2014), "Assessing graduate attributes: building a criteria-based competency model”, International Journal of Higher Education, Vol. 3 No. 3, pp. 27-38, doi: 10.5430/ijhe.v3n3p27.

Isopahkala-Bouret, U., Rantanen, T., Raij, K. and Järveläinen, E. (2011), "European Qualifications Framework and the comparison of academically-oriented and professionally-oriented master's degrees", European Journal of Higher Education, Vol. 1 No. 1, pp. 22-38, doi: 10.1080/21568235. 2011.577180.

Jerez, O., Valenzuela, L., Pizarro, V., Hasbun, B., Valenzuela, G. and Cesar, O. (2016), "Evaluation criteria for competency-based syllabi: a Chilean case study applying mixed methods", Teachers and Teaching, Vol. 22 No. 4, pp. 519-534, doi: 10.1080/13540602.2015.1082728.

Jiang, L. and Alexakis, G. (2017), “Comparing students' and managers' perceptions of essential entrylevel management competencies in the hospitality industry: an empirical study", Journal of Hospitality, Leisure, Sport and Tourism Education, Vol. 20, pp. 32-46, doi: 10.1016/j.jhlste.2017. 01.001.

Jonnaert, P., Masciotra, D., Barrette, J., Morel, D. and Mane, Y. (2007), "From competence in the curriculum to competence in action”, Prospects, Vol. 37 No. 2, pp. 187-203.

Karseth, B. (2006), "Curriculum restructuring in higher education after the Bologna Process: a new pedagogic regime?", Revista Española de Educación Comparada, No. 12, pp. 255-284.

Kennedy, D. and McCarthy, M. (2016), "Learning outcomes in the ECTS Users' Guide 2015 - some areas of concern", Journal of the European Higher Education Area, No. 16, pp. 1-16.

Klein-Collins, R. (2013), "Sharpening our focus on learning: the rise of competency-based approaches to degree completion", National Institute for Learning Outcomes Assessment, available at: https://www.learningoutcomeassessment.org/documents/Occasional\%20Paper \%2020.pdf (accessed 28 July 2020).

\section{Towards competence- oriented higher education}


ET

63,9

1388

Lans, T., Hulsink, W.I.M., Baert, H. and Mulder, M. (2008), "Entrepreneurship education and training in a small business context: insights from the competence-based approach", Journal of Enterprising Culture, Vol. 16 No. 4, pp. 363-383.

Lavonen, J. (2020), "Curriculum and teacher education reforms in Finland that support the development of competences for the twenty-first century", in Reimers, F. (Ed.), Audacious Education Purposes, Springer, Cham, Switzerland, doi: 10.1007/978-3-030-41882-3_3.

Lee, E., Carberry, A., Diefes-Dux, H., Atwood, S. and Siniawski, M. (2017), "Faculty perception before and after implementation of standards-based grading", 2017 Research in Engineering Education Symposium, REES 2017, Research in Engineering Education Network.

Levy, A., Kulmala, P., Merenmies, J., Jääskeläinen, J., Kortekangas-Savolainen, O., Jääskeläinen, J., Nikkari, S., Remes, A. and Reponen, J. (2019), "National MEDigi project: systematic implementation of digitalization to undergraduate medical and dental education in Finland", Finnish Journal of eHealth and eWelfare, Vol. 11, doi: 10.23996/fjhw.83309.

Little, P. and McMillan, M. (2014), "Graduate attributes: development and testing”, available at: https:// www.researchgate.net/publication/316453203_Graduate_Attributes_Development_and_ Testing (accessed 30 April 2019).

Mäkelä, M. and Moiso, A. (2017), "Work and study. Conceptualizing validation of work experience in a Finnish university of applied sciences", available at: https://ec-vpl.nl/view/download/entry/46/ (accessed 6 December 2020).

Mäkinen, M. and Annala, J. (2010), "Osaamisperustaisen opetussuunnitelman monet merkitykset korkeakoulutuksessa [Various aspects of the competence- based curriculum in higher education]", Kasvatus and Aika, Vol. 4 No. 4, pp. 41-61.

Mäkinen, M. and Annala, J. (2012), "Understanding curriculum in Finnish higher education”, in Ahola, S. and Hoffman, D. (Eds), Higher Education Research in Finland: Emerging Structures and Contemporary Issues, University of Jyväskylä, Finnish Institute for Educational Research, pp. 291-311, available at: https://jyx.jyu.fi/handle/123456789/42356.

Malone, K. and Supri, S. (2012), "A critical time for medical education: the perils of competence-based reform of the curriculum", Advances in Health Sciences Education: Theory and Practice, Vol. 17 No. 2, pp. 241-246.

Mayring, P. (2000), "Qualitative content analysis", Forum: Qualitative Social Research, Vol. 1 No. 2, pp. 1-10.

Moghaddam, J.M. (2011), "Perceived effectiveness of business internships: student expectations, experiences, and personality traits", International Journal of Management, Vol. 28 No. 4, pp. 287-303.

Mulder, M. and Winterton, J. (2017), "Introduction”, in Mulder, M. (Ed.), Competence-Based Vocational and Professional Education. Bridging the Worlds of Work and Education, Springer, Cham, Switzerland, pp. 1-43.

Mulder, M., Gulikers, J., Biemans, H. and Wesselink, R. (2009), “The new competence concept in higher education: error or enrichment?", Journal of European Industrial Training, Vol. 33 No. 8, pp. 755-770, doi: 10.1108/03090590910993616.

Mulkeen, J., Abdou, H., Leigh, J. and Ward, P. (2019), "Degree and higher level apprenticeships: an empirical investigation of stakeholder perceptions of challenges and opportunities", Studies in Higher Education, Vol. 44 No. 2, pp. 333-346, doi: 10.1080/03075079.2017. 1365357.

Ordonez, B. (2014), "Competency-based education: changing the traditional college degree power, policy, and practice", New Horizons in Adult Education and Human Resource Development, Vol. 26 No. 4, pp. 47-53, doi: 10.1002/nha3.20085.

Organisation for Economic Co-operation and Development (2020), "The emergence of alternative credentials: education working paper no. 216", Organisation for Economic Co-operation and Development Directorate for Education and Skills, available at: http://www.oecd.org/ 
officialdocuments/publicdisplaydocumentpdf/? cote=EDU/WKP(2020)4\&docLanguage $=$ En (accessed 28 July 2020).

Pretorius, L., Bailey, C. and Miles, M. (2013), "Constructive align graduate attributes, learning experiences, and assessment tasks in undergraduate midwifery", International Journal of Teaching and Learning in Higher Education, Vol. 25 No. 3, pp. 378-387.

Rhodes, T.L. (2012), "Show me the learning: value, accreditation, and the quality of the degree", Planning for Higher Education, Vol. 40 No. 3, pp. 36-42.

Sadler, D.R. (2005), "Interpretations of criteria-based assessment and grading in higher education", Assessment and Evaluation in Higher Education, Vol. 30 No. 2, pp. 175-194.

Salas Velasco, M. (2014), "Do higher education institutions make a difference in competence development? A model of competence production at university", Higher Education, Vol. 68 No. 4, pp. 503-523, doi: 10.1007/s10734-014-9725-1.

Sánchez Carracedo, F., Soler, A., Martín, C., López, D., Ageno, A., Cabré, J., Garcia, J., Aranda, J. and Gibert, K. (2018), "Competency maps: an effective model to integrate professional competencies across a STEM curriculum”, Journal of Science Education and Technology, Vol. 27 No. 5, pp. 448-468, doi: 10.1007/s10956-018-9735-3.

Sawyer, R.K. (2017), "Teaching creativity in art and design studio classes: a systematic literature review”, Educational Research Review, Vol. 22, pp. 99-113.

Schaffar, B. (2019), "Difficulties in defining the notion of competence", Nordic Journal of Vocational Education and Training, Vol. 9 No. 1, pp. 111-128, doi: 10.3384/njvet.2242-458X.1991111 (accessed 28 July 2020).

Schneckenberg, D., Ehlers, U. and Adelsberger, H. (2011), "Web 2.0 and competence-oriented design of learning - potentials and implications for higher education", British Journal of Educational Technology, Vol. 42, pp. 747-762, doi: 10.1111/j.1467-8535.2010.01092.x.

Schreier, M. (2012), Qualitative Content Analysis in Practice, Sage Publications, London.

Schulze, U., Kanwischer, D. and Reudenbach, C. (2013), "Essential competences for GIS learning in higher education: a synthesis of international curricular documents in the GIS\&T domain", Journal of Geography in Higher Education, Vol. 37 No. 2, pp. 257-275, doi: 10.1080/03098265. 2012.763162.

Seuring, S. and Gold, S. (2012), "Conducting content-analysis based literature reviews in supply chain management”, Supply Chain Management: An International Journal, Vol. 17 No. 5, pp. 544-555.

Struyven, K. and De Meyst, M. (2010), "Competence-based teacher education: illusion or reality? An assessment of the implementation status in Flanders from teachers' and students' points of view", Teaching and Teacher Education, Vol. 26 No. 8, pp. 1495-1510, doi: 10.1016/j.tate.2010. 05.006 .

Sun, L.P., Siklander, P. and Ruokamo, H. (2018), "How to trigger students' interest in digital learning environments: a systematic literature review", Seminar.net, Vol. 14 No. 1, pp. 62-84, available at: https://journals.hioa.no/index.php/seminar/article/view/2597 (accessed 24 July 2020).

UNESCO (2019), “Competency-based approaches”, available at: http://www.ibe.unesco.org/en/topics/ competency-based-approaches (accessed 24 July 2020).

Ushatikova, I., Rakhmanova, A., Kireev, V., Chernykh, A. and Ivanov, M. (2016), "Pedagogical bases of formation of key information technology competencies polytechnic institute graduates", International Journal of Economics and Financial Issues, Vol. 6 No. 2S.

Varga, E., Szira, Z., Bárdos, K. and Hajós, L. (2016), "The most relevant labour market competencies for employers and their assessment by students, practice and theory in systems of education", Practice and Theory in Systems of Education, Vol. 11 No. 2, pp. 95-104, doi: 10.1515/ptse2016-0012.

Walker, M. and McLean, M. (2010), "Making lives go better: university education and professional capabilities", South African Journal of Higher Education, Vol. 24, pp. 847-869. 

Employability, Vol. 1, pp. 1-24.

\section{About the author}

Dr. Sanna Brauer's doctoral dissertation from 2019 was the first in the world to address competencebased higher education and digital open badge-driven learning. Her current research focus relates to motivation, competence-oriented higher education, and the concept of desired competences. Since 2011, Brauer has been working as a senior lecturer at the Oulu University of Applied Sciences in the School of Professional Teacher Education. She is involved in various projects as well as national and international networks, and several organisations have appointed her as external expert to provide opinions and advice on specific cases related to digital pedagogy. Sanna Brauer is the corresponding author and can be contacted at: sanna.brauer@oamk.fi

For instructions on how to order reprints of this article, please visit our website: 